\title{
THE IMPLEMENTATION OF RECIPROCAL TEACHING LEARNING MODEL TO IMPROVE THE UNDERSTANDING OF PHYSIC CONCEPTS FOR OPTICAL MATERIAL IN CLASS X SMK
}

\author{
Nadya Hari Pratiwi ${ }^{* 1)}$, M. Rahmad ${ }^{2)}$, Fakhruddin Z. ${ }^{3)}$, Kartika Lona ${ }^{4)}$ \\ ${ }^{1,2,3)}$ Physics Education, University of Riau \\ 4) Vocational High School (SMK) Abdurrab Pekanbaru \\ e-mail: nadyahaypratiwi@gmail.com \\ m.rahmad@lecturer.unri.ac.id \\ faruqfisika@yahoo.com
}

\begin{abstract}
The still low understanding of the concept of students in vocational schools in learning physics, due to the lack of innovative learning, so it needs innovation such as a reciprocal teaching model that implements four independent understanding strategies, namely summarizing the material, compiling questions, explaining, and predicting. The purpose of this research was to determine the improve in understanding of students' concepts in the class applying the reciprocal teaching model with conventional classes at Vocational High School (SMK) Abdurrab Pekanbaru. The population in this research were 130 students spread over five classes and samples were taken by simple random sampling, so that 2 classes of samples were obtained with 52 students. The research instrument was in the form of concept comprehension test questions consisting of pretest and posttest. The Test in the form of multiple choice reasoned with 4 choices totaling 15 items. The instruments are arranged according to the category of understanding the concepts of translation, interpretation, and extrapolation. Data collection techniques in the form of scores on the concept understanding results obtained from the pretest and posttest scores. The data is processed by descriptive analysis. The results showed that students of class X SMK Abdurrab Pekanbaru in optical material learning, had a difference in increased understanding of concepts. The average score of concept understanding after the implementation of learning in the experimental class was 82.44 with a high category, while the control class was 59.68 with a low category. To that end, the implementation of the reciprocal teaching learning model, is able to better enhance the understanding of physics concepts in optics learning for students in class X SMK Abdurab Pekanbaru.
\end{abstract}

Keywords: reciprocal teaching, optics, understanding of concepts. 


\title{
PENERAPAN MODEL PEMBELAJARAN RECIPROCAL TEACHING UNTUK MENINGKATKAN PEMAHAMAN KONSEP FISIKA PESERTA DIDIK DI KELAS X SMK
}

\author{
Nadya Hari Pratiwi ${ }^{* 1)}$, M. Rahmad ${ }^{2}$, Fakhruddin Z. ${ }^{3)}$, Kartika Lona ${ }^{4)}$ \\ ${ }^{1,2,3)}$ Pendidikan Fisika, Universitas Riau \\ 4) SMK Abdurrab Pekanbaru
}

\begin{abstract}
Abstrak
Masih rendahnya pemahaman konsep peserta didik di SMK dalam pembelajaran fisika, karena minimnya inovasi pembelajaran, sehingga perlu inovasi seperti model reciprokal teaching yang menerapkan empat strategi pemahaman mandiri, yaitu merangkum materi, menyusun pertanyaan, menjelaskan, serta memprediksi. Tujuan penelitian ini untuk mengetahui peningkatan pemahaman konsep peserta didik pada kelas yang menerapkan model reciprocal teaching dengan kelas konvensional di SMK Abdurrab Pekanbaru. Populasi dalam penelitian ini adalah 130 peserta didik yang tersebar dalam lima kelas dan sampel diambil secara simple random sampling, sehingga diperoleh 2 kelas sampel dengan 52 peserta didik. Instrumen penelitian berupa soal tes pemahaman konsep yang terdiri dari pretest dan posttest. Soal tes berbentuk pilihan ganda beralasan dengan 4 pilihan yang berjumlah 15 butir soal. Instrumen disusun berdasarkan kategori pemahaman konsep translation, interpretation, dan extrapolation. Teknik pengumpulan data berupa skor hasil pemahaman konsep yang diperoleh dari skor pretest dan posttest. Data diolah secara analisis deskriptif. Hasil penelitian diperoleh bahwa peserta didik kelas X SMK Abdurrab Pekanbaru dalam pembelajaran materi optik, memiliki perbedaan peningkatan pemahaman konsep. Rata-rata skor pemahaman konsep setelah pelaksanaan pembelajaran di kelas eksperimen adalah 82,44 dengan kategori yang tinggi, sedangkan pada kelas kontrol adalah 59,68 dengan kategori yang rendah. Untuk itu, penerapan model pembelajaran reciprocal teaching, mampu meningkatkan lebih baik pemahaman konsep fisika dalam pembelajaran optik bagi peserta didik di kelas X SMK Abdurab Pekanbaru.
\end{abstract}

Kata Kunci : reciprocal teaching, optik, pemahaman konsep.

\section{Pendahuluan}

Pendidikan merupakan keperluan yang harus dipenuhi dalam kehidupan bermasyarakat melalui seluruh proses pembelajarannya. Hal ini dikarenakan seluruh proses kehidupan manusia selalu terdapat pembelajaran, termasuk pembelajaran sepanjang hayat manusia. Tanpa pembelajaran, manusia akan sulit berkembang bahkan akan terbelakang dalam kehidupan. Pernyataan ini sesuai dengan pendidikan sepanjang hayat (life long education) yang telah dirancang oleh organisasi pendidikan, ilmu pengetahuan dan kebudayaan PBB (UNESCO) dimana manusia memerlukan pembelajaran atau proses belajar (Fuad, 2004).

UNESCO menyatakan empat pilar pendidikan belajar dalam proses pembelajaran yakni: belajar untuk mengetahui (learning to how), belajar untuk melakukan (learning to $d o$ ), belajar untuk menjadi manusia mandiri secara utuh (learning to be) dan belajar bekerja sama (learning to live together) (Rohman \& Supari, 2014). Tujuan pendidikan yang dikemukakan UNESCO kemudian didukung oleh Pemerintah Indonesia dan menyatakan pentingnya pendidikan melalui Undangundang nomor 20 tahun 2003, tentang Sistem Pendidikan Nasional pada pasal 1 ayat 1 yang menyebutkan bahwa pendidikan adalah usaha sadar dan terencana untuk mewujudkan suasana belajar dalam proses pembelajaran agar peserta didik secara aktif mengembangkan potensi diri sehingga memiliki kekuatan spiritual, pengendalian diri, kecerdasan, serta keterampilan yang diperlukan untuk bangsa dan negara (Aris, 2014).

Pendidikan mencakup banyak ilmu yang dapat dipelajari, salah satunya adalah Ilmu Pengetahuan Alam (IPA). IPA adalah bidang ilmu yang diarahkan untuk memberitahu dan berbuat, sehingga dapat membantu peserta didik memperoleh pemahaman tentang alam 
sekitar melalui fokus kajian biologi, kimia dan fisika (Depdiknas, 2003). Ilmu fisika merupakan ilmu yang paling fundamental diantara ilmu pengetahuan alam yang lainnya. Hal ini dikarenakan dalam pembelajaran fisika memberi pengalaman untuk melakukan metode ilmiah, menggunakan prinsip dan konsep fisika untuk menjelaskan alam serta mempunyai keterampilan mengembangkan pengetahuan, dan sikap percaya diri, sehingga dapat diterapkan dalam kehidupan sehari-hari. Selain itu, ilmu fisika dapat memberikan kerangka konseptual dasar dan teoritis terhadap perkembangan ilmu pengetahuan dan teknologi (IPTEK) (Musanni et al., 2015).

Hampir semua teknologi yang ada saat ini memanfaatkan konsep-konsep fisika seperti peralatan rumah tangga, sistem panel surya, bahkan peralatan dalam dunia kesehatan. Mengingat begitu pentingnya peranan pendidikan fisika dalam kehidupan manusia, sudah semestinya ilmu fisika dipahami dengan benar dan terus dikembangkan, terutama oleh peserta didikyang harus memiliki kemampuan dasar fisika. Salah satu kemampuan yang tercantum dalam Permendikbud nomor 23 tahun 2013 adalah kemampuan pemahaman, sehingga peserta didikdi setiap tingkat pendidikan dasar dan menengah harus memiliki kemampuan pemahaman, dimana pemahaman yang dimaksud adalah pemahaman konsep-konsep fisika terutama bagi peserta didik SMK Kesehatan yang akan terjun langsung ke lapangan dan harus mampu mengaplikasikan konsep fisika.

Berdasarkan standar isi untuk pendidikan dasar dan menengah (Permendikbud, 2014) disebutkan bahwa salah satu kompetensi yang harus dicapai peserta didik Sekolah Menengah Kejuruan (SMK) Kesehatan dalam mempelajari fisika adalah memahami dan menganalisis konsep. Dengan demikian, pembelajaran fisika harus dirancang sedemikian rupa agar mampu memahami konsep-konsep fisika. Hal ini juga sesuai dengan Permendikbud nomor 60 tahun 2014 yang menyatakan bahwa SMK terdiri dari sembilan bidang keahlian dimana salah satunya adalah bidang kesehatan, maka diwajibkan untuk mempelajari fisika dan mempelajari konsep-konsepnya dikarenakan misi utama SMK adalah untuk mempersiapkan peserta didik sebagai calon tenaga kerja yang memiliki kesiapan untuk memasuki dunia kerja. Dalam dunia kesehatan, konsep fisika banyak diterapkan dalam penggunaan alat kesehatan seperti alat optik. Sehingga peserta didik harus matang dalam memahami konsep fisika yang terkait.

Berdasarkan studi pendahuluan yang dilakukan di SMK Kesehatan Abdurrab Pekanbaru untuk mengukur pemahaman konsep-konsep fisika, hanya sedikit peserta didik yang mengerti dan memahami konsepkonsep fisika dengan baik. Hal tersebut menunjukkan bahwa kemampuan pemahaman konsep peserta didik SMK cenderung masih rendah. Diantara penyebab kurangnya pemahaman fisika peserta didik adalah fasilitator yang kurang mengembangkan inovatif pembelajaran, fasilitas praktikum yang kurang memadai, silabus yang terlalu padat, jumlah mata pelajaran yang banyak (Berg,1991). Selain itu, kemampuan guru cara mengajar dan model pembelajaran yang diterapkan guru menjadi salah satu penyebab lemahnya pemahaman konsep peserta didik Suparno (2013).

Kemampuan pemahaman konsep merupakan syarat mutlak untuk mencapai keberhasilan belajar. Oleh karena itu, pemahaman konsep memiliki peranan besar untuk mendukung keberhasilan seseorang dalam belajar. Menyadari pentingnya pemahaman konsep dalam pembelajaran fisika, maka perlunya memilih model pembelajaran yang tepat. Model pembelajaran yang dapat digunakan salah satunya adalah model reciprocal teaching. Model ini akan membiasakan peserta didik menggunakan empat strategi pemahaman mandiri dalam belajar, yaitu menyimpulkan bahan ajar (summarizing), menyusun pertanyaan (questioning), menjelaskan kembali (clarifying) dan memprediksi (predicting) (Aris, 2014).

Jubeir Sulaiman Al-Harby (2016) dalam penelitiannya menyebutkan bahwa terdapat perbedaan nilai rata-rata dari hasil belajar pada kelas eksperimen dan kelas kontrol yang membuktikan bahwa model reciprocal teaching berpengaruh terhadap hasil belajar dan pemahaman konsep peserta didik. Selain itu, menurut penelitian yang dilakukan Bunga Justin Efrata (2014) membuktikan bahwa model pembelajaran reciprocal teaching mampu meningkatkan cara berpikir, berkomunikasi, berdiskusi dan belajar mandiri 
peserta didik, sehingga mereka dapat melaksanakan pembelajaran yang efektif dan bermakna dalam mengkonstruk pemahaman konsep sehingga hasil belajarnya meningkat. Oleh karena itu, kajian ini menarik diteliti tentang penerapan model pembelajaran reciprocal teaching untuk meningkatkan pemahaman konsep fisika peserta didik di kelas X SMK Abdurrab Pekanbaru.

\section{Bahan dan Metode}

Penelitian dilakukan di SMK Abdurrab Pekanbaru yang telah menerapkan Kurikulum 2013. Populasi dalam penelitian ini adalah seluruh peserta didik kelas X SMK Abdurrab Pekanbaru tahun ajaran 2018/2019 yang belum mendapatkan pembelajaran optik. Adapun sampel diambil dengan cara simple random sampling, sehingga diperoleh sampel berjumlah 2 kelas dengan 52 peserta didik.

Penelitian ini termasuk penelitian kuasi eksperimen dengan menggunakan desain penelitian the nonequivalent control grup design (Sugiyono 2012). Penelitian dilakukan dengan menguji pemahaman konsep secara langsung terhadap subjek penelitian. Instrumen penelitian berupa soal tes (pretest dan posttest) pemahaman konsep pada materi optik. Soal berupa tes tertulis dalam bentuk pilihan ganda beralasan dengan 4 pilihan yang berjumlah 15 butir soal yang telah divalidasi.

Teknik analisis data pada penelitian ini adalah analisis deskriptif. Analisis deskriptif digunakan untuk melihat gambaran hasil pemahaman konsep peserta didik dengan menggunakan kriteria pemahaman konsep tiap indikator dan peningkatan ( $N$-Gain), Tahaptahap pemberian skor iaitu: jika jawaban benar dan alasan tepat memperoleh skor 4, jika jawaban benar dan alasan kurang tepat memperoleh skor 3, jika jawaban benar dan alasan salah memperoleh skor 2, jika jawaban salah dan alasan salah memperoleh skor 1, jika tidak menjawab memperoleh skor nol. Kemudian masing-masing skor perolehan tiap indikator pada pretest dan posttest dianalisis. Untuk menghitung skor masing-masing indikator (Translation, Interpretation, Extrapolation) didapatkan skor pemahaman konsep per indikator (SPK) menurut persamaan (1):

$$
\mathrm{SPK}=\frac{\text { skor diperoleh }}{\text { skor maksimum }} \times 100 \%
$$

Adapun pengkategorian pemahaman konsep yang diperoleh dari hasil proses pembelajaran dapat digunakan kriteria sebagai berikut:

Tabel 1. Kategori pemahaman konsep

\begin{aligned} & \hline Interval (\%) $\begin{array}{c}\text { Kategori Pemahaman } \\ \text { Konsep }\end{array} \\ &$\hline $\mathrm{X} \geq 90$ Sangat Tinggi \\ & $80 \leq \mathrm{X} \leq 89$ Tinggi \\ & $65 \leq \mathrm{X} \leq 79$ Sedang \\ & $55 \leq \mathrm{X} \leq 64$ Rendah \\ & $\mathrm{X}<54$ Sangat Rendah \\ & \hline\end{aligned}

Sumber: (Nurkancana \& Sunartama, 2003).

\section{Hasil dan Pembahasan}

Melalui penelitian ini distribusi jawaban peserta didik yang menjadi sampel ditabulasikan. Hasil jawaban tersebut diinterpretasikan dan dianalisis rata-rata persentase kemampuan pemahaman konsep peserta didik setiap aspek dan rata-rata persentase secara keseluruhan menggunakan persamaan (1). Data dikelompokkan dalam 5 kategori yaitu: sangat tinggi, tinggi, sedang, rendah, dan sangat rendah. Berdasarkan hasil pengolahan diperoleh persentase pemahaman konsep peserta didik pada masing-masing aspek dan indikator sebagaimana Tabel 2 dan Tabel 3.

Aspek pemahaman konsep kelas eksperimen lebih tinggi dibandingkan kelas kontrol. Aspek translation pada pemahaman konsep memperoleh skor paling tinggi daripada aspek interpretation dan extrapolation pada kedua kelas sampel. Sedangkan aspek extrapolation memperoleh skor yang paling rendah diantara aspek yang lain. Rata-rata yang diperoleh kelas eksperimen berada pada kategori tinggi, sedangkan kelas kontrol berada pada kategori rendah. Maka pemahaman konsep pada kelas kontrol hampir semuanya belum tinggi dan masih perlu perbaikan. Hasil ini sejalan dengan Nurkancana \& Sunartana, (2003) dimana aspek pemahaman konsep dikatakan tinggi atau tuntas bila telah mencapai interval skor sebesar $65 \%$. 
Tabel 2. Hasil skor pretest aspek pemahaman konsep

\begin{tabular}{lcccc}
\hline \multirow{2}{*}{$\begin{array}{c}\text { Aspek Pemahaman } \\
\text { Konsep }\end{array}$} & \multicolumn{2}{c}{ Kelas Kontrol } & \multicolumn{2}{c}{ Kelas Eksperimen } \\
\cline { 2 - 5 } & $\begin{array}{c}\text { Skor } \\
\text { Pretest }(\%)\end{array}$ & Kategori & $\begin{array}{c}\text { Skor } \\
\text { Pretest }(\%)\end{array}$ & Kategori \\
\hline Translation & 51.73 & Sangat Rendah & 52.69 & Sangat Rendah \\
Interpretation & 48.46 & Sangat Rendah & 50.38 & Sangat Rendah \\
Extrapolation & 43.65 & Sangat Rendah & 43.65 & Sangat Rendah \\
\hline Rata-rata & 47.9 & Sangat Rendah & 48.91 & Sangat Rendah \\
\hline
\end{tabular}

Tabel 3. Hasil skor posttest aspek pemahaman konsep

\begin{tabular}{lclcl}
\hline \multirow{2}{*}{$\begin{array}{c}\text { Aspek } \\
\text { Pemahaman }\end{array}$ Konsep } & \multicolumn{2}{c}{ Kelas Kontrol } & \multicolumn{2}{c}{ Kelas Eksperimen } \\
\cline { 2 - 5 } & $\begin{array}{c}\text { Skor } \\
\text { Posttest }(\%)\end{array}$ & \multicolumn{1}{c}{ Kategori } & $\begin{array}{c}\text { Skor } \\
\text { Posttest }(\%)\end{array}$ & Kategori \\
\hline Translation & 65.77 & Sedang & 85.58 & Tinggi \\
Interpretation & 62.12 & Rendah & 84.04 & Tinggi \\
Extrapolation & 51.15 & Sangat Rendah & 77.69 & Sedang \\
\hline Rata-rata & 59.68 & Rendah & 82.44 & Tinggi \\
\hline
\end{tabular}

Rata-rata skor pemahaman konsep setelah pelaksanaan pembelajaran di kelas eksperimen adalah 82,44 dengan kategori tinggi, sedangkan rata-rata skor pemahaman konsep pada kelas kontrol adalah 59,68 dengan kategori rendah. Terdapat selisih rata-rata skor pemahaman konsep antara kedua kelas yaitu 22,76. Kelas eksperimen memperoleh hasil yang lebih tinggi daripada kelas kontrol. Hal ini dikarenakan model pembelajaran reciprocal teaching memungkinkan peserta didik untuk tau manfaat dari materi yang dipelajari bagi kehidupannya, aktif dalam kegiatan pembelajaran, menemukan sendiri konsep-konsep yang akan dipelajari, tanpa harus selalu bergantung pada guru, mampu memecahkan masalah-masalah yang berkaitan dengan konsep yang dipelajari, bekerja sama dengan peserta didik yang lain dan sudah mulai timbul keberanian mengemukakan pendapat.

Hal ini relevan dengan penelitian yang dilakukan Afriana (2017) dimana setiap aspek dari pembelajaran model reciprocal teaching yaitu merangkum, membuat pertanyaan, memprediksi dan menjelaskan kembali, membuat peserta didik menjadi lebih tertantang untuk belajar dan berusaha menyelesaikan semua permasalahan yang diberikan, sehingga pengetahuan yang diperoleh akan lebih diingat oleh peserta didik dan pemahaman konsep peserta didik dapst meningkat.

Model pembelajaran yang diterapkan di kelas kontrol adalah pembelajaran konvensional yang masih bercirikan pembelajaran berpusat pada guru. Menurut Suyatno (2012) pembelajaran konvensional cenderung membuat peserta didik lebih pasif, karena dominan mendengarkan ceramah yang diberikan guru. Sedangkan pada kelas eksperimen, peserta didik lebih mudah menyelesaikan permasalahan yang ada didalam LKPD maupun soal tes yang diberikan guru, karena pada model reciprocal teaching terdapat tahapan merangkum (summarizing) yang bertujuan untuk menentukan intisari dari materi, memberikan kesempatan untuk mengidentifikasi dan mengintegrasikan informasi yang paling 
penting dalam materi.

Peserta didik pada kelas eksperimen cenderung lebih mudah dalam mengerjakan soal-soal pada tes pemahaman konsep, karena sudah terbentuk pola pikir untuk mengorganisasikan ide-ide yang terdapat didalam soal sebelum peserta didik menentukan jawaban yang benar dan tepat. Hal ini sejalan dengan penelitian Jubeir Sulaiman Al-Harby (2016) yang menyatakan, bahwa terdapat perbedaan nilai rata-rata dari hasil belajar pada kelas eksperimen dan kelas kontrol yang membuktikan bahwa model Reciprocal teaching mampu meningkatkan hasil belajar dan pemahaman konsep peserta didik.

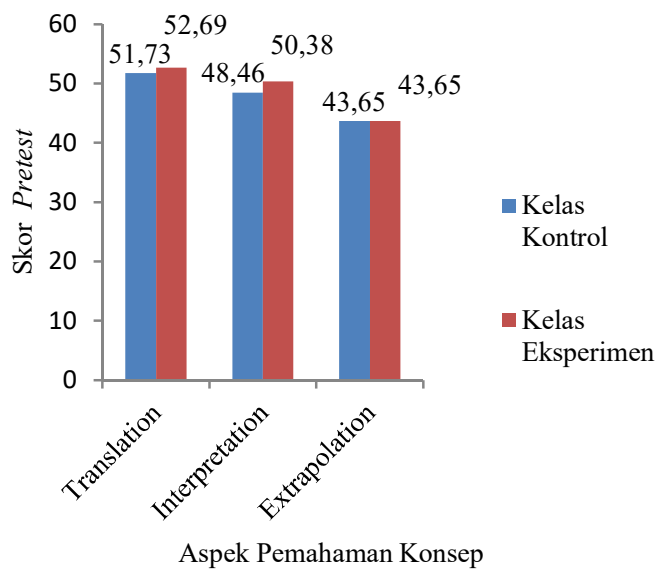

\section{Gambar 1. Hasil skor pretest aspek} pemahaman konsep.

Berdasarkan hasil analisis data pemahaman konsep tiap aspek melalui model pembelajaran reciprocal teaching terlihat pada Gambar 1 dan Gambar 2. Gambar 1 menunjukkan hubungan tiap aspek pemahaman konsep antara kelas eksperimen dan kelas kontrol masih sama. Artinya, peserta didik dari kedua kelas tersebut memiliki ratarata kemampuan yang sama dalam memahami konsep fisika dan bisa dijadikan acuan untuk melihat peningkatan pemahaman konsep melalui perlakuan yang berbeda dalam proses pembelajaran fisika terhadap kedua kelas. Sedangkan pada Gambar 2 terihat terdapat perbedaan yang cukup signifikan setelah diberikan model pembelajaran reciprocal teaching. Penjelasan untuk aspek pemahaman konsep yang meliputi tiga aspek pemahaman diuraikan pada penjelasan berikut.

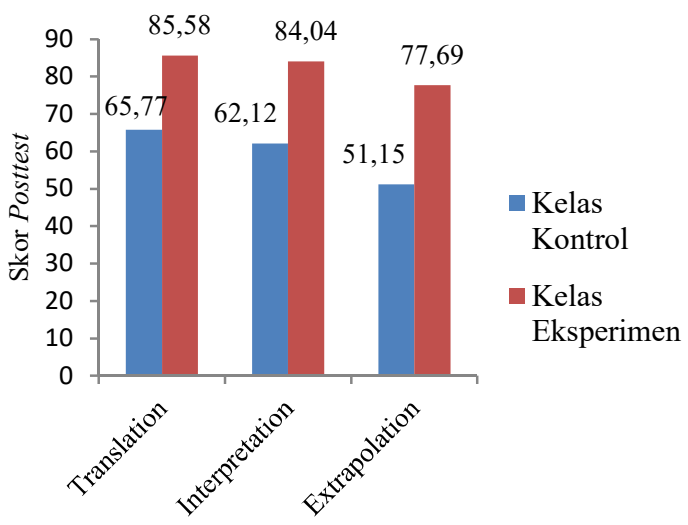

Aspek Pemahaman Konsep

Gambar 2. Hasil skor posttest aspek pemahaman konsep.

\section{Translation (Menterjemahkan)}

Pemahaman translation merupakan kemampuan menerjemahkan berkaitan dengan kemampuan peserta didik dalam menterjemahkan konsep abstraksi kepada abstraksi lain. Soal-soal aspek translation mengharapkan peserta didik mampu menerjemahkan kejadian berdasarkan gambar, menterjemaahkan sebuah data yang disajikan dalam bentuk tabel. Rata-rata skor pada aspek translation diperoleh pada kelas eksperimen lebih tinggi dibanding kelas kontrol. Kelas eksperimen memperoleh rata-rata skor 85,8 yang tergolong kategori sangat tinggi, sedangkan kelas kontrol memperoleh rata-rata skor 65,77 dengan kategori sedang. Sebenarnya kategori sedang yang diperoleh kelas kontrol dapat dikatakan cukup baik. Hal ini dikarenakan soal-soal yang pernah dikerjakan peserta didik pada saat ujian kenaikan kelas maupun contoh-contoh yang terdapat di dalam buku beberapa diantaranya mengarah ke aspek translation, sehingga dalam pengerjaan soal tes yang diberikan, peserta didik masih menggunakan pemahaman saat pembelajarn di tingkatan sebelumnya.

Selanjutnya kelas eksperimen dengan kategori sangat tinggi, menunjukkan bahwa bahwa model reciprocal teaching membantu peserta didik lebih memahami lagi penggunaan aspek translation. Aspek translation berupa persoalan dalam bentuk gambaran dari permasalahan, sehingga pada saat mengerjakan soal-soal pemahaman konsep pada aspek translation, peserta didik sudah terlatih dalam menyelesaikan masalah dan menemukan konsep yang benar dan tepat. Dengan 
demikian model pembelajaran reciprocal teaching dapat melatih peserta didik untuk menterjemahkan permasalahan. Hal ini sejalan dengan penelitian Afriana (2017) dimana model reciprocal teaching mampu membuat peserta didik menentukan intisari dari materi, memberikan kesempatan untuk mengidentifikasi dan mengintegrasikan informasi yang paling penting dalam materi pembelajaran yang diteimaanya.

\section{Interpretation (Menafsirkan)}

Pemahaman interpretation merupakan kemampuan untuk mengenal dan memahami ide utama suatu komunikasi, peserta didik diharapkan mampu menafsirkan berbagai data, memahami peristiwa yang benar berdasarkan gambar dan menemukan ide atau konsep suatu fenomena berdasarkan informasi pada soal. Hasil skor rata-rata pada aspek interpretation, kelas eksperimen memperoleh skor lebih tinggi dibanding kelas kontrol. Kelas eksperimen memperoleh rata-rata skor 84,04 dengan kategori tinggi, sedangkan kelas kontrol memperoleh rata-rata skor 62,12 dengan kategori sedang. Umumnya peserta didik kesulitan untuk memahami ide utama permasalahan, dikarenakan ketidakpahaman maksud suatu permasalahan tersebut. Kelas eksperimen memiliki pemahaman konsep interpretation tinggi. Hal ini dikarenakan pada model reciprocal teaching terdapat tahap clarifying, dimana dalam proses pembelajaran guru mengaitkan pengetahuan awal peserta didik dengan pengetahuan baru yang diterimanya.

Pengetahuan awal yang didapati peserta didik berasal dari pengalaman dalam menyelesaikan masalah yang dihadapinya. Jadi, untuk memahami maksud suatu permasalahan, peserta didik diminta untuk mengaitkan permasalahan tersebut pada pengalaman yang pernah dihadapi dan diketahui. Hal ini didukung oleh Muslim Ibrahim \& Nur Muhammad (2007) dimana peserta didik akan mudah memahami ide utama permasalahan dan membuat peserta didik memiliki beragam pemikiran terkait materi yang diajarkan, sehingga menuntut peserta didik untuk berfikir keras untuk mengetahui konsep fisika sebenarnya.

\section{Extrapolation (Memprediksi)}

Pemahaman extrapolation merupakan pemahaman konsep yang menuntut kemampuan intelektual lebih tinggi. Pada aspek ini, peserta didik diharapkan mampu menarik kesimpulan dari suatu pernyataan yang eksplisit dan membedakan nilai pertimbangan dari suatu prediksi. Rata-rata skor pada aspek extrapolation, kelas eksperimen memperoleh skor lebih tinggi dibandingkan kelas kontrol. Kelas eksperimen memperoleh rata-rata skor 77,69 kategori sedang, sedangkan kelas kontrol memperoleh rata-rata skor 51,15 kategori sangat rendah. Pemahaman extrapolation termasuk pemahaman yang susah, karena peserta dituntut untuk dapat menyimpulkan suatu permasalahan dan memprediksi. Prediksi adalah proses memperkirakan secara sistematis tentang suatu yang paling mungkin terjadi di masa depan berdasarkan informasi masa lalu dan sekarang yang dimiliki.

Kelas eksperimen memperoleh kategori sedang untuk aspek extrapolation, dikarenakan model reciprocal teaching dalam proses pembelajaran terdapat tahap predicting. Tahap ini menuntut peserta didik untuk memikirkan kembali secara mendalam konsep yang dipelajari dan mengungkapkan pendapat dalam berdiskusi maupun ketika menyajikan hasil diskusi di depan kelas. Pendapat tersebut dapat berupa prediksi akan masalah dan kesimpulan akhir permasalahan.

Contoh persoalan aspek extrapolation juga terdapat dalam LKPD, sehingga peserta didik terlatih untuk mengerjakan soalan yang berhubungan dengan aspek extrapolation. Hal ini sejalan dengan penelitian yang dilakukan oleh Nurwahidah et al., (2012) dimana model reciprocal teaching membuat peserta didik mampu menjelaskan kembali ataupun memprediksi terutama ketika belajar dengan peserta didik yang memiliki sejarah kesulitan yang berbeda. Strategi ini memberikan penekanan kepada peserta didik untuk menjadi guru dihadapan teman- temannya.

Secara keseluruhan apabila merujuk pada hasil $N$-Gain untuk melihat masingmasing perubahan peningkatan pemahaman konsep terlihat bahwa terdapat selisih antara pemahaman konsep kelas kontrol dan eksperimen. Tidak banyak perubahan peningkatan pemahaman konsep peserta didik kelas kontrol dalam materi optik, sedangkan kelas eksperimen diperoleh rata-rata skor 
pretest sebesar 48,91 dan rata-rata posttest sebesar 82,44, sehingga diperoleh gain 0,66 yang artinya kelas eksperimen mengalami peningka-tan pemahaman konsep dengan kategori sedang. Hal ini sesuai dengan Hake (2002) dimana untuk interval gain $0,7>\mathrm{g}>0,3$ yang menandakan bahwa model pembelajaran yang digunakan pada kelas eksperimen tersebut efektif, karena terdapat peningkatan pemahaman konsep peserta didik yang signifikan. Sedangkan jika gain $<0,3$ menandakan bahwa model pembelajaran konvensional pada kelas kontrol tidak efektif karena hampir tidak ada peningkatan pemahaman konsep peserta didik.

Oleh karena itu, berdasarkan hasil analisis data secara deskriptif dan inferensial menunjukan bahwa pemahaman konsep peserta didik antara kelas kontrol dan kelas eksperimen terdapat perbedaan yang signifikan, dimana pada kelas eksperimen pemahaman konsepnya mengalami peningkatan yang lebih tinggi, jadi model pembelajaran reciprocal teaching efektif untuk membantu peserta didik meningkat pemahaman konsep fisika pada materi optik.

Kelebihan penelitian menggunakan model reciprocal teaching ini adalah mampu melatih kemampuan peserta didik memahami konsep lebih baik, sehingga hasil belajar fisika peserta didik akan meningkat. Mampu melatih peserta didik untuk menjelaskan kembali materi yang dipelajari kepada pihak lain. Peserta didik dapat mempresentasi kan idenya, peserta didik dapat menemukan dan menyelidiki sendiri konsep yang sedang dibahas, serta peserta didik akan lebih mudah dalam mengingat suatu konsep.

Walaupun penerapan model pembelajaran reciprocal teaching telah mampu meningkatkan pemahaman konsep peserta didik, namun masih ditemukan kendala seperti ketidaksungguhan para peserta didik secara optimal berperan sebagai guru, peserta didik masih malu dan tidak percaya diri untuk menjadi guru, pendengar ataupun peserta didik yang tidak berperan sering menertawakan tingkah laku peserta didik yang berperan sebagai guru, sehingga membuat situasi kelas kurang kondusif. Selain itu, model ini juga jika tidak dikondisikan ketepatan waktunya membutuhkan waktu yang lama hingga terkadang ada peserta didik yang tidak berkesempatan untuk menjadi fasilitator. Oleh karena itu, agar tujuan tercapai dengan menggunakan model ini, maka guru sebagai fasilitator harus mampu mengatasi dengan pembiasaan dalam proses pembelajaran, sehingga peran guru yang dibebankan kepada peserta didik dapat terlaksana lebih baik dan optimal. Begitu juga dengan peserta didik lainnya yang berperan sebagai pendengar dapat terealisasi dengan baik.

\section{Kesimpulan dan Saran}

Berdasarkan penelitian yang telah dilaksanakan di SMK Abdurrab Pekanbaru, maka dapat disimpulkan secara analisis deskriptif terdapat tingkat pemahaman konsep pada aspek translation, interpretation dan extrapolation yang berbeda antara kelas eksperimen dengan kelas konvensional. Tingkat pemahaman konsep pada kelas eksperimen yang menerapkan model pembelajaran reciprocal teaching berada pada kategori lebih tinggi. Secara analisis inferensial terdapat perbedaan pemahaman konsep yang signifikan antara kelas yang menerapkan model reciprocal teaching dibandingkan kelas konvensional pada peserta didik kelas X SMK Abdurrab Pekanbaru. Oleh karenanya, penerapan model pembelajaran reciprocal teaching mampu meningkatkan pemahaman konsep peserta didik kelas $\mathrm{X}$ SMK Abdurrab Pekanbaru pada materi optik.

Direkomendasikan model reciprocal teaching dapat diterapkan dengan mengoptimalkan peran peserta didik sebagai guru dan meminimalisir kendala lainnya. Model ini dapat digunakan sebagai salah satu alternatif dalam pembelajaran fisika yang inovatif. Disarankan juga untuk menerapkan pada materi pokok yang berbeda dan bidang ilmu yang berbeda, guna meningkatkan mutu pendidikan dimasa yang akan datang.

\section{Daftar Pustaka}

Afriana, Rovi, 2017. Pengaruh Model Reciprocal Teaching terhadap Hasil Belajar pada Konsep Fluida Statis. Skripsi. Universitas Islam Negeri Syarif Hidayatullah, Jakarta.

Al-Harby, Jubeir Suleiman Samir, 2016. The 
Effect of Reciprocal-Teaching Strategy on Learning Outcomes and Attitudes of Qassim-University Students in Islamic Culture. Journal of Education and Practice, 7(6): 1-10.

Aris, Shoimin, 2014. 68 Model Pembelajaran Inovatif dalam Kurikulum 2013. Ar-Ruz Media, Yogyakarta.

Berg, E., 1991. Salah Konsep dalam Pendidikan Fisika. UKSW, Salatiga.

Depdiknas, 2003. Undang-Undang nomor 20 Tahun 2003 Tentang Sistem Pendidikan Nasional. Departemen Pendidikan Nasional.

Bungah Justin Efrata, 2014. Peningkatan Hasil Belajar dengan Menggunakan Metode Pembelajaran Terbalik (Reciprocal Teaching) pada Peserta didik Kelas X Teknik Gambar Bangunan untuk Mata Diklat Ilmu Bangunan Gedung di SMK Negeri 5 Surabaya". Jurnal Kajian Pendidikan Teknik Bangunan, Surabaya, 1(1):14-27.

Fuad, Hasan, 2004. Pendidikan adalah Pembudayaan dalam Pendidikan Manusia Indonesia. Kompas, Jakarta.

Hake R.R., 2002. Relationship of Individual Student Normalized Gain in Mechanics with Gender, High School Physics, and Pretest Score on Mathematic and Spatial Visualization. Diakses pada 10 Maret 2019 dari http:/www.physics.indiana. edu/hake.

Musanni, Susilawati, \& Hadiwijaya, A.S., 2015. Pengembangan Bahan Ajar Fisika SMA Berbasis Learning Cycle 3E pada
Materi Pokok Teori Kinetik Gas dan Termodinamika. Jurnal Penelitian Pendidikan IPA, 1(1): 56-64.

Muslimin Ibrahim, \& Nur Muhammad. 2007. Penelitian dan Penilaian Pendidikan. Sinar Baru Algensindo, Bandung.

Nurkancana, W., \& Sunartama, P., 2003. Evaluasi Hasil Belajar. Usaha Nasional, Surabaya.

Nurwahidah, I., Sarwi, \& Handayani, L., 2012. Penerapan Model Pembelajaran Reciprocal Teaching Berbasis Kooperatif untuk Meningkatkan Pemahaman Konsep Fisika Siswa Kelas X. Unnes Physics Education Journal of Education, 1(2): 25-32. UNNES. Semarang.

Permendikbud, 2014. Peraturan Meteri Pendidikan dan Kebudayaan no. 59 Tahun 2014 Tentang Kurikulum 2013 SMA. Depdikbud, Jakarta.

Rohman \& Supari, 2014. Studi Implementasi Empat Pilar Pendidikan Rekomendasi UNESCO Dengan Model PEmbelajaran Berdasarkan Masalah Pada Standar Kompetensi Dasar pada SMK Negeri 7 Surabaya. Jurnal Pendidikan Teknik Elektro, 1(3): 46.

Sugiyono, 2012. Metode Penelitian Pendidikan (Pendekatan Kuantitatif, Kualitatif, $R \& D)$. Al-Fabeta, Bandung.

Suparno, P., 2013. Miskonsepsi \& Perubahan Konsep dalam Pendidikan Fisika. Gramedia Widiasarana, Jakarta.

Suyatno, 2012. Metode Penelitian Pendidikan dan Pengembangan. Rajawali, Jakarta. 